\title{
HOW IS THE WORKING CONVENIENCE OF AIR TRAFFIC CONTROLLER AT HALIM PERDANAKUSUMA AIRPORT JAKARTA (STUDY CASE ON 2012)
}

\author{
Agit Prasetiyo ${ }^{1}$ \\ 1.STMT Trisakti \\ corresponding author : agitprasetiyo@gmail.com
}

\begin{abstract}
Air Traffic Controller has an important role of air safety. They works sometimes underpressure to be able decide a most important decision while working to ensure safety. With some pressure like that they need a comfort place to work and a good environment to work with it. The objective of this research is to describe the working convenience and the working environment of Air Traffic Controller at HalimPerdanakusuma Airport Jakarta. This research used description method to describe the real condition of control tower cabin at HalimPerdanakusuma Airport Jakarta. The data was taken by questionnaire to20 Persons holder license of Air Traffic Controller who has control rating to control the vicinity od aerodrome of HalimPerdanakusuma Airport Jakarta. Some of them will got an interview to explore their explanation regarding convenience at work. The result of the research is $48,8 \%$ respondent said uncomfortable while working, $38,6 \%$ respondent said moderate, and the remain $12,8 \%$ said comfortable. Based on recent information, some improvement have been done to increase working convenience and working environment of controller.

Keywords: Air Traffic Controller, Convenience, Safety, License
\end{abstract}

\section{Introduction}

Indonesia is an archipelago country. It consist of small islands and large islands spreading from Sabang to Merauke. To connecting those islands, needed an efficient and effective transportation mode. Air transport is an alternative to connect those island. That is the reason of high demand in air transportation an effect the growth of air traffic recently.

The growth of air traffic lead into density of the traffic. In order to manage the density of those traffic we need Air Traffic Controller to ensure safety and efficiency of the flight. So then we can fly safe and efficiently.

The increasing of air traffic in a certain airport should simultaneously with increasing service quality of air traffic at that airport. One of the effort to increase the service quality of air traffic is by increasing the facility that could support the controller in working with it. Those facilities used in daily work so it has direct effect to the controller while giving air traffic services. There are some factors that could determine the working convenience, those 
are temperature, noise level, and lights level. In addition, the design of desk control for Air Traffic Controller. If the convenience has been achieved then it will be able to support good performance of Air Traffic Controller.

The convenience level should be maintain in order to support the people who work in it. If the level of comfortable cannot be achieved, then it possible to reduce the performance of the people who work in it. The reduction of performance of Air Traffic Controller could influence the quality of service of air traffic service. If the quality of service is decreasing then it could endanger the safety of the flight. it means, it could be danger for the flight safety.

\section{Literature Review}

Here are some literature that related to this research.

Table 1. Literature Review

\begin{tabular}{|c|c|c|c|c|c|c|}
\hline Researcher & Title & Variable & Analysis & Result & Comparison & Source \\
\hline $\begin{array}{l}\text { Dinar, Eko, } \\
\text { and } \\
\text { Hanifah } \\
(2016)\end{array}$ & $\begin{array}{l}\text { Analysis } \\
\text { factor of } \\
\mathrm{K} 3 \text { on } \\
\text { cargo } \\
\text { handling } \\
\text { in } \\
\text { Soekarno- } \\
\text { Hatta } \\
\text { Internatio } \\
\text { nal } \\
\text { Airport }\end{array}$ & $\begin{array}{l}\text { Health } \\
\text { and } \\
\text { Safety } \\
\text { Factor }\end{array}$ & $\begin{array}{l}\text { Quantitat } \\
\text { ive } \\
\text { Research } \\
\text { with } \\
\text { Survey }\end{array}$ & $\begin{array}{l}\text { The value of } \\
\text { health and } \\
\text { safety culture } \\
\text { are above } \\
\text { score/index } \\
\text { average } 5.0 \\
\text { which means } \\
\text { that in } \\
\text { general the } \\
\text { whole in } \\
\text { individual in } \\
\text { this section } \\
\text { posses the } \\
\text { moderate } \\
\text { level of } \\
\text { health and } \\
\text { safety values. }\end{array}$ & $\begin{array}{l}\text { Similar topic } \\
\text { about health } \\
\text { and safety } \\
\text { factor. But } \\
\text { the different } \\
\text { is there are } \\
\text { different } \\
\text { factors for } \\
\text { view. }\end{array}$ & $\begin{array}{l}\text { Ejourn } \\
\text { al.stmt } \\
- \\
\text { trisakti } \\
\text {.ac.id } \\
\text { Vol 3, } \\
\text { No. 1. }\end{array}$ \\
\hline
\end{tabular}


Table 1, Cont. Literature Review

\begin{tabular}{|c|c|c|c|c|c|c|}
\hline $\begin{array}{l}\text { Mustika } \\
\text { Sari (2016) }\end{array}$ & $\begin{array}{l}\text { Factors } \\
\text { causing } \\
\text { the } \\
\text { irregulariti } \\
\text { es of } \\
\text { airplane } \\
\text { medical } \\
\text { evacuatio } \\
\text { n handling } \\
\text { in Halim } \\
\text { Perdanaku } \\
\text { suma } \\
\text { Airport }\end{array}$ & $\begin{array}{l}\text { Airplane } \\
\text { medical } \\
\text { evacuati } \\
\text { on } \\
\text { handling }\end{array}$ & $\begin{array}{l}\text { Qualitati } \\
\text { ve } \\
\text { Descripti } \\
\text { ve using } \\
\text { observati } \\
\text { on, } \\
\text { question } \\
\text { nare and } \\
\text { interview }\end{array}$ & $\begin{array}{l}\text { The } \\
\text { irregularities } \\
\text { of handling } \\
\text { medevac is } \\
\text { cause by } \\
\text { some factor } \\
\text { such as old } \\
\text { GSE } \\
\text { equipment } \\
\text { that more } \\
\text { than } 20 \text { years } \\
\text { old, } \\
\text { inoperative } \\
\text { equipment, } \\
\text { no SOP and } \\
\text { less human } \\
\text { resource } \\
\text { management. }\end{array}$ & $\begin{array}{l}\text { Similar } \\
\text { location at } \\
\text { Halim } \\
\text { Perdanakusu } \\
\text { ma Airport } \\
\text { and } \\
\text { exploring } \\
\text { about } \\
\text { working } \\
\text { facilities. } \\
\text { But different } \\
\text { topic to } \\
\text { explore. }\end{array}$ & $\begin{array}{l}\text { Ejourn } \\
\text { al.stmt } \\
- \\
\text { trisakti } \\
\text {.ac.id } \\
\text { Vol.03 } \\
\text { No.03 }\end{array}$ \\
\hline $\begin{array}{l}\text { Andri, } \\
\text { Roswan, } \\
\text { and Endang } \\
\text { (2016) }\end{array}$ & $\begin{array}{l}\text { Halim } \\
\text { Perdanaku } \\
\text { suma } \\
\text { Airport } \\
\text { Service } \\
\text { and } \\
\text { Husein } \\
\text { Sastraneg } \\
\text { ara } \\
\text { Airport } \\
\text { Service. }\end{array}$ & $\begin{array}{l}\text { Airport } \\
\text { Service } \\
\text { consist } \\
\text { of } \\
\text { responsi } \\
\text { veness, } \\
\text { assuranc } \\
\text { e, } \\
\text { tangible } \\
\text { s, } \\
\text { emphaty } \\
\text { and } \\
\text { reliabilit } \\
\text { y to } \\
\text { consume } \\
\text { r } \\
\text { satisfacti } \\
\text { on }\end{array}$ & $\begin{array}{l}\text { Qualitati } \\
\text { ve } \\
\text { Research }\end{array}$ & $\begin{array}{l}\text { Halim } \\
\text { Perdanakusu } \\
\text { ma airport } \\
\text { level service } \\
\text { is at quadran } \\
2 \text { Husein } \\
\text { Sastranegara } \\
\text { airport level } \\
\text { service at } \\
\text { quadran } 1 .\end{array}$ & $\begin{array}{l}\text { Similar } \\
\text { location at } \\
\text { Halim } \\
\text { Perdana } \\
\text { kusuma } \\
\text { Airport. } \\
\text { Different } \\
\text { variable to } \\
\text { explore. }\end{array}$ & $\begin{array}{l}\text { Ejourn } \\
\text { al.stmt } \\
- \\
\text { trisakti } \\
\text {.ac.id } \\
\text { Vol 3, } \\
\text { No. 1. }\end{array}$ \\
\hline $\begin{array}{l}\text { Resky and } \\
\text { Juliater } \\
(2014)\end{array}$ & $\begin{array}{l}\text { Function } \\
\text { and } \\
\text { Weakness } \\
\text { of } \\
\text { Operation } \\
\text { Service } \\
\text { Unit in } \\
\text { Airport }\end{array}$ & $\begin{array}{l}\text { Airport } \\
\text { Operatio } \\
\mathrm{n} \text { consist } \\
\text { of } \\
\text { Airport } \\
\text { Service, } \\
\text { Airport } \\
\text { Security } \\
\text { and } \\
\text { Airport } \\
\text { Safety }\end{array}$ & $\begin{array}{l}\text { Descripti } \\
\text { ve } \\
\text { Qualitati } \\
\text { ve }\end{array}$ & $\begin{array}{l}\text { Operation } \\
\text { Service Unit } \\
\text { is the } \\
\text { frontline of } \\
\text { customer } \\
\text { satisfaction. } \\
\text { It should be } \\
\text { fill by } \\
\text { qualified } \\
\text { personnel } \\
\text { that has high } \\
\text { competency } \\
\text { level and } \\
\text { excellent } \\
\text { facilities to } \\
\text { increase the } \\
\text { reputation of } \\
\text { an airport. }\end{array}$ & $\begin{array}{l}\text { Similarities } \\
\text { in service } \\
\text { effort to the } \\
\text { costumer. } \\
\text { But different } \\
\text { variable to } \\
\text { explore. }\end{array}$ & $\begin{array}{l}\text { Jurnal } \\
\text { manag } \\
\text { ement } \\
\text { Bisnis } \\
\text { Transp } \\
\text { ortasi } \\
\text { dan } \\
\text { Logisti } \\
\text { k, } \\
\text { Vol.1 } \\
\text { No.1 }\end{array}$ \\
\hline
\end{tabular}


Table 1, Cont. Literature Review

\begin{tabular}{|c|c|c|c|c|c|c|}
\hline $\begin{array}{l}\text { Ricky and } \\
\text { Charles } \\
(2015)\end{array}$ & $\begin{array}{l}\text { Best Air } \\
\text { Traffic } \\
\text { Control } \\
\text { Tower on } \\
\text { European- } \\
\text { African } \\
\text { Regional }\end{array}$ & $\begin{array}{l}\text { The } \\
\text { height } \\
\text { and } \\
\text { design } \\
\text { of the } \\
\text { tower } \\
\text { and the } \\
\text { relations } \\
\text { hip to } \\
\text { the airport } \\
\text { capacity }\end{array}$ & $\begin{array}{l}\text { Descripti } \\
\text { ve } \\
\text { Qualitati } \\
\text { ve }\end{array}$ & $\begin{array}{l}\text { Soekarno- } \\
\text { Hatta Airport } \\
\text { result from } \\
\text { the height of } \\
\text { tower is } 61 \\
\mathrm{M} \text { and the } \\
\text { design score } \\
\text { is } 14 \text {. }\end{array}$ & $\begin{array}{l}\text { Similar in } \\
\text { viewing the } \\
\text { structural } \\
\text { requirement } \\
\text { of tower } \\
\text { cab. But the } \\
\text { different is } \\
\text { this research } \\
\text { doesn't } \\
\text { explore the } \\
\text { facilities }\end{array}$ & $\begin{array}{l}\text { Jurnal } \\
\text { manag } \\
\text { ement } \\
\text { Bisnis } \\
\text { Transp } \\
\text { ortasi } \\
\text { dan } \\
\text { Logisti } \\
\text { k, } \\
\text { Vol.2 } \\
\text { No.1 }\end{array}$ \\
\hline
\end{tabular}

The definition of working convenience has a close relation with working environment. So then, the definition of working convenience will describe the working environment it self. Working with convenience means a condition where working environment is in a supporting condition for the workers so they can work maximal.

A good working condition marked by good air circulation, a bright lightning and far away from disturbing noise that could disturb working concentration, besides that a good room layout and clean will make a good feeling to work (Anoraga,1992). Defining that theory, we conclude there are some factors that effect comfort, those are temperature, light intensity, level of noise and working facility that available on that working environment.

That statement support by the expert of organizational behaviour Stephen P. Robbins. There are 3 (three) factors of working convenience. First is level of noise. Noise is one of the human life pollution. In a long term, noise could endanger working convenience, reduce listening capability, and supporting wrong communication or disrupt messages. A serious level of noise could resulting in death. Human capabilities in hearing voice in on frequency of $16-20.000 \mathrm{~Hz}$, and the intensity of 84 desibel constantly. The intensity that more than $85 \mathrm{~dB}$ could effect the disturbance of hearing and the limit called critical level intensity. The influence of noise exposure generally divided into 2 (two) groups based on the noise intensity and interval of time. First one called high influence of noise exposure (above threshold value) and second is low influence of noise exposure (below threshold value). The high influence of noise exposure could damage 
the sense of hearing by reducing hearing capability, whether temporary or permanent (deaf). The high influence of noise exposure will really disturbing if the intensity is now and then without knowing the real source of the noise. Physiologically, the high influence of noise exposure contributes in health problems such as high blood pressure and heart rate, increasing heart attack risk, and indigestion. In society, if noise is produced by a production process sometimes they requested to stop the production. Meanwhile, low influence of noise exposure could contribute stress or anger, headache, and insomnia. It also could disturb psychomotor reaction, reducing concentration, and reducing performance of work that effecting low efficiency and productivity.

The second factor that could effect working convenience is temperature. Human always maintain his body in a normal condition using perfect metabolism system by adapting the change outside his body into it. The temperature below $37^{\circ}$ Celsius means air temperature is below his ability to adapt with outside condition ( $35 \%$ below normal temperature), so the body will experiencing cold condition, because it lose the heat of the body caused by convection and radiation, and some evaporation. Otherwise, if the air temperature is higher than the body's temperature it will absorb the heat caused by convection and radiation that far away higher than his body ability to cooling down his body using evaporation system. The effect is the temperature of the body getting higher parallel with air temperature. The lowest temperature will reduce the working passion, but the highest temperature will make the body exhausted and tend to make mistakes. The different of level temperature will give different influence to the body as well (Sutalaksana,1979). The influence of air temperature $49^{\circ} \mathrm{C}$ will give direct effect to the physical and mental of human. In $30^{\circ} \mathrm{C}$, the mentality and respond activity are decreasing and tend to make mistakes, and then getting exhausted. The optimum air temperature for human is $24^{\circ} \mathrm{C}$. But in $\pm 10^{\circ} \mathrm{C}$ human will show extreme physical behaviour.

The third factor that could effect working convenience is lighting. Lighting defined as the amount of light that pour into the surface.This factor 
contributes into working satisfaction and working convenience in direct manner. Good lighting is the lighting that accommodates worker to see small object to work in a fast and clear vision without any useless effort. Good lighting and intensity will contributes in producing good and conform working environment and working mood that could maintain the working passion. The standard room lighting that require high accuracy in working should be at 500-1.000 Lux (Munandar, 2001). Theeffect of less illumination are eyestrain, mental fatigue, stiffness around the neck and headache, and eye damage. Finally it will reduce productivity, lower working quality, and fatal work accident.

The last factor is air quality. We cannot deny that inhaling polluted air quality will endanger workers health and environment. In long term, it will cause headache, eye irritation, fatigue, stress, and depression.

Working environment is a place where the employees do day-to-day work. Physical working environment consist every facilities starting from parking lot outside building, location, and building design, specifically until the sound and illumination of an employee working space (Munandar, 2001). For an Air Traffic Controller working on Aerodrome Control Tower position working space called Control Tower Room or Tower. That is the reason why a control tower should comply with such international standard regulation and also human factor. Document 9426 Air Traffic Service Planning Manual, Part 3, Chapter 2 Specific Requirement for an Aerodrome Control Tower should follow operational requirement. The example of operational requirement such as the tower controller should be able to watch all his area of jurisdiction from the tower cabin. The control tower must be provided by the capability to communicate rapidly, clearly, and reliably with aircraft in his area responsibility. Since operation to and around a control tower generate a fair amount of noise (example radios, aircraft engines, talking), the provision of sound deadening feature in control tower is very important. Therefore, the acoustic qualities should be taken into account in the selection of structural material used for control tower construction. Sound-deadening materials should also be used internally, 
example carpet or similar sound-absorbent material (dust free and antistatic, if possible) should cover the cab floor and the walls up to the window sills. The layout of working positions within the tower cab and the consequential arrangement of operating consoles will obviously be determined by the location of tower in relation to the manoeuvring area, and more especially, the approach direction which is most frequently used at the aerodrome in question. It should also be noted, because of the responsibilities, and the frequent stress involved in the provision of Air Traffic Controller, the provision of other than purely operational facilities contribute to no small degree to the efficiency of the service provided and, as such, deserve careful consideration (Document 9426 Air Traffic Service Planning Manual, Part 3, Chapter 2 Specific Requirement for an Aerodrome Control Tower, 1984).

The structural requirement is also important in Air Traffic Controller working environment. Ideally a control tower should be of the required height and should have ample space to ensure an optimum working environment for personnel and equipment (including expansion capacity), be energy efficient, durable and aesthetically pleasing - all at moderate cost. The space for the tower cab should be ample but not excessive. As its size increase the controller's viewing angle out the opposite side of the tower cab becomes more limited by the height of the window sill (downward) an the roof line (upward). Similarly, physical co-ordination problems between controllers increase with larger space. United States suggest polygonic cabs of the following dimensions (Document 9426 Air Traffic Service Planning Manual, Part 3, Chapter 2 Specific Requirement for an Aerodrome Control Tower, 1984): 


\begin{tabular}{|c|c|c|}
\hline $\begin{array}{l}\text { Level of } \\
\text { Activity }\end{array}$ & $\begin{array}{l}\text { Approximate Number of } \\
\text { Personnel } \\
\text { Simultaneously Present } \\
\text { in the Cab }\end{array}$ & $\begin{array}{c}\text { Cab } \\
\text { Area } \\
\text { (Square } \\
\text { Metre) }\end{array}$ \\
\hline Low & Not more than 6 & 21 \\
\hline Intermediate & Between 6-12 & 32 \\
\hline Major & Norethab12 & 50 \\
\hline
\end{tabular}

Table 1. Suggest Polygonic Dimensions

In addition, the size control cab should be primarily dependent on the number, location and size of control position and consoles.

Another important aspect is accommodation. Document 9426 Air Traffic Service Planning Manual, Part 3, Chapter 2 specify the operational equipment that should be available in a control tower (Appendix 1). The tower cab should be fitted with consoles to house equipment and provide desk space of the same height as the consoles for writing as well as space to mount monitoring equipment such as aerodrome lighting panels, telephone and radio selector panels and brackets to hold microphone and telephone handsets. The console desk should also provide support for flight progress strip holders and should have radio/telephone connexions, including those used for monitoring. There should be drawers for pens, pencils, paper, etc. Drink holders as well as ashtray should be located safely away from radio and telephone selector panels and other equipment sensitive to liquid or ash spilling. A supervisor's $\operatorname{desk}(\mathrm{s})$ should be provided with necessary telephone and radio terminals and a bookcase should be able to keep appropriate reference material (Document 9426 Air Traffic Service Planning Manual,1984). The tower cabin with low activity, suggested to have a convenience unit to facilitate controller in providing some food and meals without leaving working positions. For the tower shaft, primary use for working room or lavatory. If the lavatory located not in the tower cab, the location should be put downstairs in an easy way to get by controller. Regarding the thermal environment, it consist of temperature, humidity, and air flow rates. Most Air Traffic Controller work in a chair and do not move so much. Sometimes they have to stand up to see the vicinity. With this 
condition, the recommended temperature is $21^{\circ} \mathrm{C}-25^{\circ} \mathrm{C}$ (Human Factors Digest 8, 1993).

\section{Discussion and Result}

The total of ATC License Holder overall is 20 persons with aerodrome control tower rating. The total respondents is 14 persons, 4 (four) persons is taking short course, another 2 (two) did not give any answers.. The total of question in a questionnaire is 10 (ten) questions, 5 (five) questions about working convenience, another 5 (five) questions is about problem in working convenience. The 10 questions spread random and mix between working convenience and the problem in working convenience in order to make an objectives result. The results are as follow:

a) Question number 1 (one) regarding lighting level of tower cab to see night traffic operation results as follow:

Table 2. Result for Qusetion number 1

\begin{tabular}{|c|l|c|c|}
\hline No. & Classification & $\begin{array}{c}\text { Respondent } \\
\text { Total }\end{array}$ & Percent. \\
\hline A & Inconvenience & 8 & $57.1 \%$ \\
\hline B & Moderate & 6 & $42.9 \%$ \\
\hline C & Convinience & 0 & $0 \%$ \\
\hline & Total & 14 & $100 \%$ \\
\hline
\end{tabular}

The percentage shows $57.1 \%$ of respondent said feel inconvenience regarding working convenience by lighting level of tower cab to see night traffic operation. The reason taken by interview is they hard to see the position of aircraft in the night because the glare in the tower cab.

b) Question number 3 (three) regarding facilities in controlling aircraft result as follow : 
Table 3. Result for Qusetion number 3

\begin{tabular}{|c|l|c|c|}
\hline No. & Classification & $\begin{array}{c}\text { Respondent } \\
\text { Total }\end{array}$ & Percent. \\
\hline A & Inconvenience & 5 & $35.8 \%$ \\
\hline B & Moderate & 8 & $57.1 \%$ \\
\hline C & Convinience & 1 & $7.1 \%$ \\
& Total & 14 & $100 \%$ \\
\hline
\end{tabular}

The percentage shows $78.6 \%$ of respondentfeel inconvenience regarding working convenience by facilities in controlling, such lack of binoculars.

c) Question number 5 (five) regarding the noise inside tower cab that could destroying concentration in controlling aircraft, result as follow:

Table 4. Result for Qusetion number 5

\begin{tabular}{|c|c|c|c|}
\hline No. & Classification & $\begin{array}{c}\text { Respondent } \\
\text { Total }\end{array}$ & Percent. \\
\hline A & Inconvenience & 0 & $0 \%$ \\
\hline B & Moderate & 6 & $42.9 \%$ \\
\hline C & Convinience & 8 & $57.1 \%$ \\
\hline & Total & 14 & $100 \%$ \\
\hline
\end{tabular}

The percentage shows $57.1 \%$ of respondent feel moderate regarding working convenience by noise inside the tower cab that could destroy concentration.

d) Question number 7 (seven) regarding air quality inside tower cab result as follow :

Table 5. Result for Qusetion number 7

\begin{tabular}{|c|l|c|c|}
\hline No. & Classification & $\begin{array}{c}\text { Respondent } \\
\text { Total }\end{array}$ & Percent. \\
\hline A & Inconvenience & 11 & $78.6 \%$ \\
\hline B & Moderate & 3 & $21.4 \%$ \\
\hline C & Convinience & 0 & $0 \%$ \\
\hline & Total & 14 & $100 \%$ \\
\hline
\end{tabular}

The percentage shows $57.1 \%$ of respondent feel convenience regarding working convenience by air quality inside tower cab. 
e) Question number 10 (ten) regarding air temperature inside tower cab result as follow :

Table 5. Result for Qusetion number 10

\begin{tabular}{|c|l|c|c|}
\hline No. & Classification & $\begin{array}{c}\text { Respondent } \\
\text { Total }\end{array}$ & Percent. \\
\hline A & Influence & 9 & $64.3 \%$ \\
\hline B & Moderate & 5 & $35.7 \%$ \\
\hline C & Non-influence & 0 & $0 \%$ \\
\hline & Total & 14 & $100 \%$ \\
\hline
\end{tabular}

The percentage shows $71.4 \%$ of respondent feel inconvenience regarding working convenience by air temperature that too cold.

f) Question number 2 (two) regarding saturation level in working environment result as follow :

Table 6. Result for Qusetion number 2

\begin{tabular}{|c|l|c|c|}
\hline No. & \multicolumn{1}{|c|}{ Classification } & $\begin{array}{c}\text { Respondent } \\
\text { Total }\end{array}$ & Percent. \\
\hline A & Influence & 2 & $14.3 \%$ \\
\hline B & Moderate & 10 & $71.4 \%$ \\
\hline C & Non-influence & 2 & $14.3 \%$ \\
\hline & Total & 14 & $100 \%$ \\
\hline
\end{tabular}

The percentage shows $64.3 \%$ of respondent feel working enviroment influencing saturation level of working inside tower cab.

g) Question number 4 (four) regarding contribution of air quality into working convenience result as follow :

Table 7. Result for Qusetion number 4

\begin{tabular}{|c|c|c|c|}
\hline No. & Classification & $\begin{array}{c}\text { Respondent } \\
\text { Total }\end{array}$ & Percent. \\
\hline A & Inconvenience & 10 & $71.4 \%$ \\
\hline B & Moderate & 4 & $28.6 \%$ \\
\hline C & Convinience & 0 & $0 \%$ \\
\hline & Total & 14 & $100 \%$ \\
\hline
\end{tabular}

The percentage show $71.4 \%$ of respondent feel contribution of air quality has no influence into working convenience.

h) Question number 6 (six) regarding the availability of working facilities inside tower cab result as follow : 
Table 8. Result for Qusetion number 6

\begin{tabular}{|c|l|c|c|}
\hline No. & Classification & $\begin{array}{c}\text { Respondent } \\
\text { Total }\end{array}$ & Percent. \\
\hline A & Influence & 12 & $85.7 \%$ \\
\hline B & Moderate & 2 & $14.3 \%$ \\
\hline C & Non-influence & 0 & $0 \%$ \\
\hline & Total & 14 & $100 \%$ \\
\hline
\end{tabular}

The percentage shows the availability of working facility influencing working convenience.

i) Question number 8 (eight) regarding night lamp availability for working convenience result as as follow :

Table 9. Result for Qusetion number 8

\begin{tabular}{|c|l|c|c|}
\hline No. & Classification & $\begin{array}{c}\text { Respondent } \\
\text { Total }\end{array}$ & Percent. \\
\hline A & Influence & 10 & $71.4 \%$ \\
\hline B & Moderate & 4 & $28.6 \%$ \\
\hline C & Non-influence & 0 & $0 \%$ \\
\hline & Total & 14 & $100 \%$ \\
\hline
\end{tabular}

The percentage shows $85.7 \%$ of respondent feel night lamp availability influence working convenience especially for night traffic operations.

j) Question number 9 (nine) regarding air temperature level inside tower cab to working convenience result as follow :

Table 10. Result for Qusetion number 9

\begin{tabular}{|c|l|c|c|}
\hline No. & \multicolumn{1}{|c|}{ Classification } & $\begin{array}{c}\text { Respondent } \\
\text { Total }\end{array}$ & Percent. \\
\hline A & Influence & 11 & $78.6 \%$ \\
\hline B & Moderate & 3 & $21.4 \%$ \\
\hline C & Non-influence & 0 & $0 \%$ \\
\hline & Total & 14 & $100 \%$ \\
\hline
\end{tabular}

The percentage show $71.4 \%$ of respondent feel air temperature level inside tower cab influencing working convenience. 
Table 11. The sum of overall results

\begin{tabular}{|c|c|c|c|c|c|c|c|c|c|c|}
\hline Question & 1 & 3 & 5 & 7 & 10 & 2 & 4 & 6 & 8 & 9 \\
\hline Respondent & \multicolumn{5}{|c|}{ Working Convenience } & \multicolumn{5}{|c|}{$\begin{array}{c}\text { Contributing Factor/ Working } \\
\text { Environment }\end{array}$} \\
\hline 1 & B & A & B & B & A & B & B & A & A & A \\
\hline 2 & B & A & B & $\mathrm{C}$ & A & A & B & A & A & A \\
\hline 3 & $\mathrm{~A}$ & $\mathrm{~A}$ & B & $\mathrm{C}$ & $\mathrm{A}$ & $\mathrm{B}$ & B & A & A & $\mathrm{B}$ \\
\hline 4 & A & A & $\mathrm{B}$ & $\mathrm{C}$ & B & A & $\mathrm{B}$ & A & A & $\mathrm{B}$ \\
\hline 5 & $\mathrm{~A}$ & $\mathrm{~A}$ & $\mathrm{~B}$ & B & A & $\mathrm{A}$ & $\mathrm{A}$ & $\mathrm{A}$ & A & B \\
\hline 6 & A & A & A & B & B & A & B & A & A & A \\
\hline 7 & B & B & A & $\mathrm{C}$ & B & A & $\mathrm{C}$ & A & A & A \\
\hline 8 & A & B & B & $\mathrm{C}$ & A & B & $\mathrm{C}$ & B & A & A \\
\hline 9 & B & A & B & B & A & A & A & B & A & $\mathrm{C}$ \\
\hline 10 & B & $\mathrm{A}$ & A & $\mathrm{C}$ & A & A & B & B & A & A \\
\hline 11 & $\mathrm{~A}$ & $B$ & $\mathrm{C}$ & $\mathrm{C}$ & $\mathrm{A}$ & $\mathrm{A}$ & B & $\mathrm{A}$ & A & $\mathrm{C}$ \\
\hline 12 & A & A & A & $\mathrm{C}$ & A & A & B & A & A & $\mathrm{C}$ \\
\hline 13 & A & A & A & B & A & B & B & A & B & A \\
\hline 14 & B & A & B & B & B & B & B & A & B & A \\
\hline \multirow{3}{*}{ Total } & $A=8$ & $A=11$ & $A=5$ & $A=0$ & $A=10$ & $A=9$ & $A=2$ & $A=11$ & $A=12$ & $A=8$ \\
\hline & $B=6$ & $\mathrm{~B}=3$ & $\mathrm{~B}=8$ & $\mathrm{~B}=6$ & $\mathrm{~B}=4$ & $B=5$ & $\mathrm{~B}=10$ & $\mathrm{~B}=3$ & $\mathrm{~B}=2$ & $\mathrm{~B}=3$ \\
\hline & $\mathrm{C}=0$ & $\mathrm{C}=0$ & $\mathrm{C}=1$ & $\mathrm{C}=8$ & $\mathrm{C}=0$ & $\mathrm{C}=0$ & $\mathrm{C}=2$ & $\mathrm{C}=0$ & $\mathrm{C}=0$ & $\mathrm{C}=3$ \\
\hline \multirow{3}{*}{$\begin{array}{l}\text { GRAND } \\
\text { TOTAL }\end{array}$} & \multicolumn{5}{|c|}{$A=34$} & \multicolumn{5}{|c|}{$\mathrm{A}=42$} \\
\hline & \multicolumn{5}{|c|}{$B=27$} & \multicolumn{5}{|c|}{$B=23$} \\
\hline & \multicolumn{5}{|c|}{$\mathrm{C}=9$} & \multicolumn{5}{|c|}{$\mathrm{C}=5$} \\
\hline
\end{tabular}

From the data of the research regarding working convenience of Air Traffic Controller at HalimPerdanakusuma Airport Jakarta and also contributing factor effect on it result as follow:

a) The working convenience level of Air Traffic Controller at HalimPerdanaKusuma Jakarta.

The total percentage of respondents stated convenience are:

$$
\frac{9}{70} \times 100 \%=12.8 \%
$$

The total percentage of respondent stated moderate are :

$\frac{27}{70} \times 100 \%=38.6 \%$ 
The total percentage of respondent stated inconvenience are:

$\frac{34}{70} \times 100 \%=48.6 \%$

Based on the data above, we conclude that $48.6 \%$ of Air Traffic Controllers feel inconvenience while working. Furthermore, the graphic describe as follow:

\section{Convenience Level Graphic}

$\begin{aligned} & \text { CONVENIENCE }= \\ & 12.8 \% \\ & \text { MODERATE }=38.6 \% \\ & \text { INCONVENIENCE = } \\ & 48.6 \%\end{aligned}$

Graph 1. Convenience Level Graphic

b) The influence of contributing factor or working environment to working convenience of Air Traffic Controller at HalimPerdanakusuma Airport Jakarta.

The total percentage of respondents stated influence are :

$\frac{42}{70} \times 100 \%=60 \%$

The total percentage of respondent stated moderate are :

$\frac{23}{70} \times 100 \%=32.8 \%$

The total percentage of respondent stated non-influence are :

$\frac{5}{70} \times 100 \%=7.2 \%$

Based on the data above, we conclude that $60 \%$ of Air Traffic Controller feel contributing factor or working environment influence the working convenience while working. Furthermore, the graphic describe as follow: 


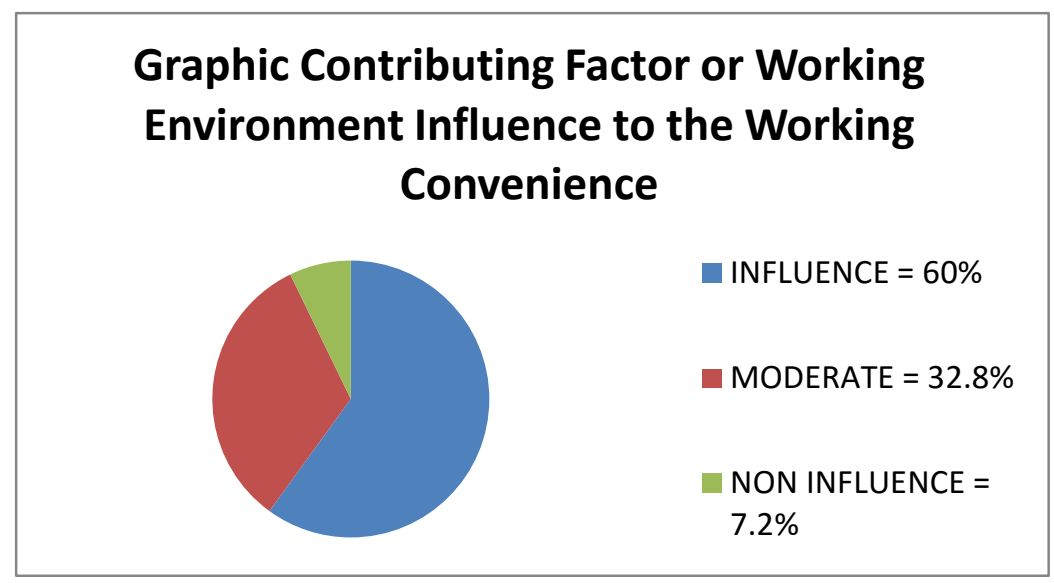

Graph 2. Contributin Factor Or Working Environment Influence To The Working Convenience Graphic

\section{Result}

From the problem above until the data result from the field by questionnaire and interview we conclude that $57.1 \%$ Air Traffic Controllers feel inconvenience while working in night time operations due difficulties in night observation. Glare inside tower cabin from the mirror of tower cab become contributing factor in it. The solution we offer is provide night lamp that focus on desk control to lighting working media such as paper, flight progress strip, and othe facilities without lighting the whole room. Lighting whole room using common room lamp causing glare effect that disturbing Controllers observation on field.

Supporting facilities such as binoculars, gun light, and all facilities mentioned by Appendix B Check-list for Aerodrome Control tower and Approach Control Operations Equipment should be provided in tower cab to make easier way of working.

From the data above $71.4 \%$ of 14 respondents feel air temperature did not set well. The temperature is too cold for human. The low air temperature should be pointed to the equipment to reduce the heat, but it is not suitable for human. Centralized air conditioner could be an option to fix this problem. 


\section{Conclusion}

Based on data we conclude that $48.6 \%$ Air Traffic Controller feels inconvenience on working convenience while working, other $38.6 \%$ feels moderate or enough, and the remain $12.8 \&$ feels convenience while working.

Meanwhile, $60 \%$ of Air Traffic Controllers feels the contributing factor or working environment influencing their working convenience while working.

We suggest comprehensive improvement of Air Traffic Controller working convenience and working environment by renewing desk control design, lighting system, air circulation system, and noise reduction. Some facilities such as ergonomic chair, radio selector panel, night lamp for desk control, binocular, and strip holder should improved in quality and also quantity. The more convenience controller in working, the sky could be safer.

\section{References}

Aminarno Budi Pradana, Drs, S.SiT, Metode Penelitian Ilmiah. Sekolah Tinggi Penerbangan Indonesia, Curug-Tangerang, 2005.

Andri dkk, Maret 2016, Halim Perdanakusuma Airport Service and Husin Sastranegara Airport Service, Jurnal Manajemen Transportasi dan Logistik (JM Translog) Vol-03 No.01, http://ejournal.stmttrisakti.ac.id/index.php/jmtranslog/article/view/143/101, November 2017.

Dinar Dewi Kania dkk, Maret 2016, Analysis Factor of K3 on Cargo Handling in Soekarno-Hatta International Airport, Jurnal Manajemen Transportasi dan Logistik (JM Translog) Vol-03 No.01, http://ejournal.stmt-

trisakti.ac.id/index.php/jmtranslog/article/view/142/93, November 2017.

Human Factor Digest 8, Human Factor for Air Traffic Control, 1993. International Civil Aviation Organization 1984, Document 9426, Air Traffic Services Planning Manual,First Edition, Montreal.

International Civil Aviation Organization 2004, Annex 14, Aerodromes, fourthedition, July, Chapter 1.

Munandar.AsharSunyoto, Psikologi Industri dan Organisasi, Jakarta : UIPress, 2001

Panji Anoraga. Drs, Psikologi Kerja, Jakarta : Rineka Cipta, 1992.

Peraturan Pemerintah Nomor 71 Tahun 1996 Tentang Daerah Kerja. 
Reski dan Juliater, September 2014, Function and Weakness of Operation Service Unit in Airport, Jurnal Manajemen Transportasi dan Logistik (JM Translog) Vol-01 No.01, http://library.stmttrisakti.ac.id/jurnal/index.php/JMBTL/article/view/4, November 2017.

Ricky dan Charles, September 2015, Best Air Traffic Control Tower on European-African Regional, Jurnal Manajemen Transportasi dan Logistik (JM Translog) Vol-02 No.01, http://library.stmttrisakti.ac.id/jurnal/index.php/JMBTL/article/view/36, November 2017.

Robbins. Stephen P, Organization Behaviour, $9^{\text {th }}$ edition (perilaku organisasi, edisi ke-9), edisi Indonesia, Alih Bahasa TIM INDEKS, Jakarta : PT Indeks Kelompok Gramedia,2003.

Sari. Mustika, November 2016, Factors causing the irregularities of airplane medical evacuation handling in Halim Perdanakusuma Airport, Jurnal Manajemen Transportasi dan Logistik (JM Translog) Vol-03 No.03, http://ejournal.stmttrisakti.ac.id/index.php/jmtranslog/article/view/79/35, November 2017.

Sutalaksa dkk, Teknik Tata Cara Kerja, Jurusan Teknik Industri, Bandung : ITB, 1979.

Surat Keputusan Direktorat Jendral Perhubungan Udara nomor :SKEP.77/VI/2005, tentang persyaratan teknis pengoperasian fasilitas teknik Bandar Udara.

Undang-Undang Nomor 1 Tahun 1970 Tentang Keselamatan Kerja

Undang-UndangNomor 1 Tahun 2009 Tentang Penerbangan

\section{Appendix A}

List of Questionnare

1. Do you feel any difficulties to see the traffic position on night time operation?
a. Always
b. Sometimes
c. Never

2. Does recent working environment influence your saturation while working?
a. Yes, it does
b. Moderate
c. No, it doesn't

3. When you need any facilities to support your duty, do you feel any difficulties to reach them?

a. Always 

b. Sometimes
c. Never

4. Does air quality inside tower cab influence your working convenience?
a. Yes, it does
b. Moderate
c. No, it doesn't

5. Do you feel any difficulties to be concentrate on your duty due to noise inside tower cab?
a. Always
b. Sometimes
c. Never

6. Does the availability of working facilities now influence your working convenience?
a. Yes, it does
b. Moderate
c. No, it doesn't

7. Do you feel stuffy while working?
a. Always
b. Sometimes
c. Never

8. Does night lamp availability influence your working convenience?
a. Yes, it does
b. Moderate
c. No, it doesn't

9. Does air temperature level inside tower cab influence your working convenience?
a. Yes, it does
b. Moderate
c. No, it doesn't

10. Do you feel cold while working?

a. Always 

b. Sometimes
c. Never

\section{Appendix B}

\section{CHECK-LIST}

AERODROME CONTROL TOWER AND APPROACH CONTROL OPERATIONS EQUIPMENT

\begin{tabular}{|c|c|c|}
\hline $\begin{array}{l}\text { Tower } \\
\text { only }\end{array}$ & $\begin{array}{l}\text { APP in } \\
\text { Tower cab }\end{array}$ & $\begin{array}{c}\text { Separate } \\
\text { APP }\end{array}$ \\
\hline$x$ & $\mathbf{x}$ & $\mathbf{x}$ \\
\hline $\mathbf{x}$ & $\mathbf{x}$ & $\mathbf{x}$ \\
\hline$x$ & $\mathbf{x}$ & $\mathbf{x}$ \\
\hline $\mathbf{x}$ & $\mathbf{x}$ & $\mathbf{x}$ \\
\hline $\mathbf{x}$ & $\mathbf{x}$ & $\mathbf{x}$ \\
\hline $\mathbf{x}$ & $\mathbf{x}$ & $\mathbf{x}$ \\
\hline$x$ & $\mathbf{x}$ & $\mathbf{x}$ \\
\hline $\mathbf{x}$ & $\mathbf{x}$ & $x$ \\
\hline$x$ & $x$ & $x$ \\
\hline $\mathbf{x}$ & $\mathbf{x}$ & $\mathbf{x}$ \\
\hline $\mathrm{x}^{*}$ & $x$ & $x$ \\
\hline $\mathrm{x}$ & $x$ & \\
\hline$x$ & $x$ & $x$ \\
\hline$x$ & $\mathrm{x}$ & \\
\hline$x$ & $x$ & $x$ \\
\hline $\mathbf{x}$ & $\mathbf{x}$ & $\mathbf{x}$ \\
\hline $\mathrm{x}$ & $\mathrm{x}$ & \\
\hline$x$ & $x$ & $x$ \\
\hline$x$ & $\mathrm{x}$ & $x$ \\
\hline \multirow[t]{4}{*}{$\mathrm{x}^{*}$} & $\mathbf{x}$ & \\
\hline & & $\mathbf{x}$ \\
\hline & $x$ & $x$ \\
\hline & & $\mathrm{x}$ \\
\hline \multirow[t]{2}{*}{$\mathbf{x}$} & $\mathbf{x}$ & $x$ \\
\hline & $\mathrm{x}$ & $\mathrm{x}$ \\
\hline \multirow[t]{2}{*}{$x$} & $\mathrm{x}$ & $x$ \\
\hline & $\mathbf{x}$ & $x$ \\
\hline $\mathrm{x}$ & $x$ & $\mathrm{x}$ \\
\hline $\mathrm{x}$ & $\mathrm{x}$ & $\mathrm{x}$ \\
\hline $\mathbf{x}$ & $\mathrm{x}$ & $\mathbf{x}$ \\
\hline $\mathrm{x}$ & $\mathbf{x}$ & \\
\hline $\mathrm{x}$ & $x$ & $\mathrm{x}$ \\
\hline \multirow[t]{3}{*}{$x$} & & \\
\hline & $\mathrm{x}$ & $\mathrm{x}$ \\
\hline & $\mathbf{x}$ & $x$ \\
\hline $\mathrm{x}$ & $\mathrm{x}$ & $\mathrm{x}$ \\
\hline $\mathrm{x}$ & $\mathrm{x}$ & \\
\hline $\mathrm{x}$ & $\mathrm{x}$ & $\mathrm{x}$ \\
\hline
\end{tabular}

1. Headset

2. Microphone

3. Transceiver

4. Speakers

5. Radio selector panel

6. Telephone selector panel/handsets

7. Intercom

8. Auto-switch headset/speaker

9. Recorder (radio and telephone)

10. Power

11. Back-up power

12. Signal lamp and reel

13. Wind speed and direction display

14. Barometric altimeter

15. Altimeter setting indicator

16. Clock

17. Aerodrome lighting pane

18. Navaid(s) monitor panel

19. Lighting, including emergency lights

20. Daylight radar/display consoles

21. Radar displays, controls, consoles

22. Secondary radar controls

23. Kadar simulator

24. Flight data panel

25. Automation equipment

26. Clipboards/displays (NOTAM etc.)

27. ATIS recorder

28. Fire alarm and extinguishers

29. Desks/consoles/shelves

30. Chairs

31. Shades

32. Air conditioning, heating/cooling

33. Convenience group (hot-plate/water, etc.)

34. Lunch facility

35. Water fountain

36. Bookcases

37. Binoculars

38. Sound-absorbing coverings (floor/wall)

* Where necessary due to particular circumstances. 